This is an author produced version of a paper published in Preventive Veterinary Medicine. This paper has been peerreviewed and is proof-corrected, but does not include the journal pagination.

Citation for the published paper:

Hultgren, J., Svensson, C., 2009. Heifer rearing conditions affect length of productive life in Swedish dairy cows.

Preventive Veterinary Medicine 89, 255-264.

doi:10.1016/j.prevetmed.2009.02.012

http://www.sciencedirect.com/science/article/pii/S01675877090 00440

Access to the published version may require journal subscription.

Published with permission from: Elsevier

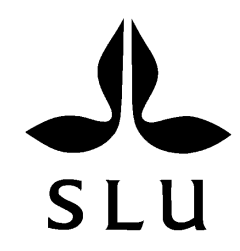

Epsilon Open Archive http://epsilon.slu.se 


\title{
Heifer rearing conditions affect length of productive life in Swedish dairy cows
}

\author{
Jan Hultgren*, Catarina Svensson \\ Department of Animal Environment and Health, Swedish University of Agricultural Sciences, \\ P.O. Box 234, SE-53223 Skara, Sweden
}

\begin{abstract}
Associations between rearing conditions and the risk of culling in dairy cows were studied by survival analysis. Data were collected from 1039 Swedish Red cows, 1029 Swedish Holsteins, and 56 cows of other milk or cross-breeds, representing all female animals born in 109 Swedish herds during 1998. Length of productive life was defined as the number of days from 1st calving to culling. The applied Weibull proportional hazards model included time-independent effects of breed, housing from 3 to 7 months of age, number of housing changes before calving, grazing before 1st calving, herd median age at 1st calving, age at 1st calving, cow housing, herd lactational incidence risk of veterinary-reported clinical mastitis, and the random effect of herd. Time-dependent effects were year, month, the interaction year by month, parity, number of breedings, pregnancy status, the interaction parity by pregnancy status, herd mean milk-production level, relative milk yield within breed-parity, and veterinary-reported clinical mastitis. The lactation was divided into six stages in which pregnancy status was assumed to be known by the farmer and culling could occur. Median productive life time in culled cows was $780 \mathrm{~d}$ and $14 \%$ of the records were censored due to terminated data collection. An individual calving age of 28.2-30.9 months was associated with the highest culling risk, 1.2-fold higher than calving at $\leq 25.3$ months, whereas the risk decreased almost linearly with a higher herd median age at $1^{\text {st }}$ calving. Housing in slatted pens with $>7$ calves from 3 to 7 months was associated with a 1.7-fold increase in risk, relative to litter pens. If a cow had changed housing system 4 times before 1st calving it increased the risk of culling 1.4 times, relative to two housing changes. These results show that rearing factors affect the productive life time of dairy cows in Swedish family operations.
\end{abstract}

Keywords: Culling; Dairy cattle; Health; Length of productive life; Rearing; Replacement heifer; Survival

\footnotetext{
* Corresponding author. Tel.: +46 511 67103; fax.: +46 511 67204. E-mail address: jan.hultgren@hmh.slu.se (J. Hultgren)
} 


\section{Introduction}

Culling of dairy cattle is costly. Replacement heifers need to be reared and incorrect timing of culling might lead to a suboptimal use of limited resources. Next to feed costs, replacement costs are the second largest expense for the dairy enterprise (Goodger et al., 1989). Among the most important factors affecting replacement costs is age at $1^{\text {st }}$ calving (Tozer and Heinrichs, 2001). Age at 1st calving is also reported by several authors to be negatively correlated with survival after calving (Gill and Allaire, 1976; Ponce de León and Guzmán, 1989; Schneider et al., 2007). To maximize farmer profit, calving at 24 months or less has therefore been recommended (Ettema and Santos, 2004; Nilforooshan and Edriss, 2004). Nevertheless, a higher mean calving age is reported in Sweden (Swedish Dairy Association, 2007) and elsewhere.

Culling decisions are based mainly on economic considerations. The farmer expects to improve profit by replacing a cow, considering factors such as conformation, temperament, age, stage of lactation, level of milk production, pregnancy, and health. Accounting for approximately $25 \%$ of total culls each, mastitis and impaired fertility are the most common reasons for culling in Swedish dairy cattle (Swedish Dairy Association, 2007). Mastitic cows have a greater risk of being culled than healthy cows (Rajala-Schultz and Gröhn, 1999b; Neerhof et al., 2000; Schneider et al., 2007), and several authors (e.g. Beaudeau et al., 1995; Schneider et al., 2007) have reported cows with poor reproductive performance to be at an increased risk of culling.

It is important for advisers and producers to recognize rearing factors that might have an influence on later performance and longevity in the herd. However, apart from age at 1st calving, the literature offers little guidance regarding rearing factors that influence cow survival. Study of the influence of calfhood rearing and health on length of productive life in commercial herds is labourious and time-consuming, because it requires longitudinal data from early age to culling. Hitherto, such data have not been available and used extensively. Previous studies on long-term effects of calfhood health (e.g. Britney et al., 1984; Warnick et al., 1994) included few animals and thus suffered from limited statistical power.

Our objective was to study associations of factors related to heifer rearing with culling and length of productive life in Swedish commercial dairy herds. Calfhood housing and disease, prepubertal growth, and feeding before and around 1st calving were of special interest.

\section{Material and methods}

\subsection{Herds and recordings}

In October 1997, we mailed a questionnaire to 485 dairy farms situated in the county of Skaraborg in southwest Sweden, concerning the housing and management of replacement heifers, and an enquiry about participation in a longitudinal study. The questionnaire recipients comprised all milk producers with herds of 28-94 cows enrolled in the Swedish official milk- and health-recording schemes (Andersson, 1988; Emanuelson, 1988), except 36 farmers who local veterinary practitioners and agricultural advisers recognized as not capable of keeping reliable calf records. The herd size interval was chosen to represent viable Swedish family operations. The response rate was $58 \%$ and 122 farmers expressed willingness to participate. All 3081 heifer calves born in these herds during 1998 were enrolled. Among these animals, 2243 were reported to calve in the study herds. After editing and exclusion of incomplete data, 2124 cow lifetime records from 109 herds were possible to include in the 
present study. The cows were Swedish Reds (49\%), Swedish Holsteins (48\%), of other milk breeds (e.g. Jersey) or crosses.

Information was collected from the official milk- and health-recording schemes, from farmer forms and interviews, and through direct on-farm observations by research staff. The farms were visited at least bimonthly to check animal records. One of three project veterinarians made most $(>70 \%)$ of the visits, examined the heifers physically and recorded diseases not noted by the farmers. Diarrhoea was defined as abnormally soft faeces for $>2 \mathrm{~d}$. Respiratory disease was defined as either coughing or sneezing for $>2 \mathrm{~d}$, or severely increased respiratory sounds at lung auscultation, or moderately increased respiratory sounds together with coughing, sneezing or nasal discharge. The project veterinarians categorised each recorded case of diarrhoea or respiratory disease as mild or severe, based mainly on information from the farmers. Cases associated with a reduced general condition or appetite for $>2 \mathrm{~d}$ or with obvious weight loss of the diseased calf were denoted as severe, and remaining cases were classified as mild. The calves' health until $210 \mathrm{~d}$ was described by Svensson et al. (2003, 2006a). Body weight was estimated from heart girth at birth, at weaning, at turn-outs to and housings from pasture (or, if not grazed, at corresponding time points), and at 1 st breeding. Throughout the rearing period, grazing was generally practised for 2-4 months from May to September; median total grazing time until calving was 6.7 months. In 48 herds, young calves were vaccinated routinely against ringworm. No other vaccination occurred.

Productive life was defined in accordance with Schneider et al. (2007) as number of days from 1st calving to culling (slaughter, spontaneous death or selling off live) or to censoring. Records were defined as censored when cows were lost to follow-up due to incomplete production records, the herd was sold or left the study, or when cows were still alive in their home herds at the end of recording on 3 May 2006. Coding animals sold live as censored did not change the results markedly.

\subsection{Statistical analysis}

Data were edited and descriptive statistics created in JMP Statistical Discovery software (Release 6; SAS Institute Inc., Cary, NC, USA). To analyse the effect of heifer rearing conditions on length of productive life, we applied analytical methods similar to those used by Schneider et al. (2007). Modeling was done using the Survival Kit, a set of Fortran programs designed by Ducrocq and Sölkner (1998), applying the following proportional hazards model:

$$
f(t ; \mathbf{x}(t) ; \mathbf{z})=f_{0}(t) \exp \left[\mathbf{x}^{\prime}(t) \mathbf{b}+\mathbf{z}^{\prime} \mathbf{u}\right]
$$

where $f(t)$ is the hazard function of a cow $t$ days after $1^{\text {st }}$ calving; $f_{0}(t)$ the baseline hazard function $\left[\lambda \rho(\lambda t)^{\rho-1}\right]$ following a Weibull distribution with scale parameter $\lambda$ and shape parameter $\rho ; \mathbf{x}^{\prime}(t)$ a vector of (possibly time-dependent) fixed covariates with corresponding parameter vector $\mathbf{b}$; and $\mathbf{z}$ ' a vector of random covariates reflecting herd identity (frailty) with corresponding parameter vector $\mathbf{u}$.

A selection of variables considered in the model are described in Table 1. Initially, the random-intercept effect of herd and important confounders of rearing effects based on earlier research (year, month, year by month interaction, parity, pregnancy status, parity by pregnancy status interaction, breed) were forced in. Thereafter, the model was built by testing potentially interesting independent variables (rearing factors and additional confounders) by including them one by one in a forward manner, retaining only those significant at $\mathrm{P} \leq 0.05$ in approximate likelihood-ratio tests, based on the associated changes in log pseudo-likelihood 
Table 1

Descriptive statistics for a selection of variables considered when studying the risk of culling in 1828 culled and 296 censored Swedish dairy cows born in 109 herds during 1998.

\begin{tabular}{|c|c|c|c|}
\hline \multirow[b]{2}{*}{ Variable } & \multirow[b]{2}{*}{ Class } & \multicolumn{2}{|c|}{ Number $(\%)$ of cows } \\
\hline & & Culled & Censored \\
\hline Age at $1^{\text {st }}$ calving & $\begin{array}{l}\leq 770 \mathrm{~d} \\
771-811 \mathrm{~d} \\
812-859 \mathrm{~d} \\
860-941 \mathrm{~d} \\
>941 \mathrm{~d}\end{array}$ & $\begin{array}{l}380(21) \\
377(21) \\
364(20) \\
363(20) \\
344(19)\end{array}$ & $\begin{array}{l}48(16) \\
46(16) \\
60(20) \\
61(21) \\
81(27)\end{array}$ \\
\hline Breed & $\begin{array}{l}\text { Swedish Red } \\
\text { Swedish Holstein } \\
\text { Other or cross }\end{array}$ & $\begin{array}{l}899(49) \\
882(48) \\
47(2.6)\end{array}$ & $\begin{array}{c}140(47) \\
147(50) \\
9(3.0)\end{array}$ \\
\hline Cow housing & $\begin{array}{l}\text { Cubicles } \\
\text { Short-stalls } \\
\text { Long-stalls }\end{array}$ & $\begin{array}{l}434(24) \\
1002(55) \\
392(21)\end{array}$ & $\begin{array}{l}68(23) \\
163(55) \\
65(22)\end{array}$ \\
\hline Grazing before $1^{\text {st }}$ calving & $\begin{array}{l}\text { No } \\
\text { Yes }\end{array}$ & $\begin{array}{c}84(4.6) \\
1744(95)\end{array}$ & $\begin{array}{l}25(8.4) \\
271(92)\end{array}$ \\
\hline $\begin{array}{l}\text { Herd lactational incidence risk } \\
\text { of clinical mastitis }\end{array}$ & $\begin{array}{l}\leq 0.094 \\
0.095-0.16 \\
>0.16 \\
\text { Missing }\end{array}$ & $\begin{array}{l}571(31) \\
600(33) \\
652(36) \\
5(0.27)\end{array}$ & $\begin{array}{c}108(36) \\
88(30) \\
100(34) \\
0\end{array}$ \\
\hline $\begin{array}{l}\text { Herd mean milk production } \\
\text { per year }\end{array}$ & $\begin{array}{l}\leq 7370 \mathrm{~kg} \mathrm{ECM} \\
7371-8054 \mathrm{~kg} \mathrm{ECM} \\
>8054 \mathrm{~kg} \mathrm{ECM}\end{array}$ & $\begin{array}{l}917(50) \\
522(29) \\
389(21)\end{array}$ & $\begin{array}{l}148(50) \\
95(32) \\
53(18)\end{array}$ \\
\hline Herd median age at $1^{\text {st }}$ calving & $\begin{array}{l}\leq 785 \mathrm{~d} \\
786-811 \mathrm{~d} \\
812-842 \mathrm{~d} \\
843-889 \mathrm{~d} \\
>889 \mathrm{~d}\end{array}$ & $\begin{array}{l}324(18) \\
363(20) \\
451(25) \\
383(21) \\
307(17)\end{array}$ & $\begin{array}{l}31(10) \\
61(21) \\
59(20) \\
74(25) \\
71(24)\end{array}$ \\
\hline Herd size & $\begin{array}{l}<45 \text { cows } \\
46-70 \text { cows } \\
71-90 \text { cows } \\
\geq 91 \text { cows }\end{array}$ & $\begin{array}{l}286(16) \\
528(29) \\
628(34) \\
386(21)\end{array}$ & $\begin{array}{c}40(14) \\
78(26) \\
107(36) \\
71(24)\end{array}$ \\
\hline Housing from 3 to $7 \mathrm{mo}$ & $\begin{array}{l}\text { Litter pen } \leq 12 \text { calves } \\
\text { Litter pen }>12 \text { calves } \\
\text { Slatted pen } \leq 7 \text { calves } \\
\text { Slatted pen }>7 \text { calves } \\
\text { Other }\end{array}$ & $\begin{array}{l}583(32) \\
143(7.8) \\
828(45) \\
200(11) \\
74(4.0)\end{array}$ & $\begin{array}{l}88(30) \\
26(8.8) \\
137(46) \\
27(9.1) \\
18(6.1)\end{array}$ \\
\hline $\begin{array}{l}\text { Number of housing changes } \\
\text { before } 1^{\text {st }} \text { calving }\end{array}$ & $\begin{array}{l}2 \\
3 \\
4\end{array}$ & $\begin{array}{c}410(22) \\
1009(55) \\
409(22)\end{array}$ & $\begin{array}{l}66(22) \\
165(56) \\
65(22)\end{array}$ \\
\hline Parity at culling/censoring & $\begin{array}{l}1 \\
2 \\
3 \\
4 \\
5 \\
6 \\
7\end{array}$ & $\begin{array}{c}561(31) \\
539(29) \\
356(19) \\
222(12) \\
126(6.9) \\
23(1.3) \\
1(0.1)\end{array}$ & $\begin{array}{c}1(0.3) \\
11(3.7) \\
57(19) \\
77(26) \\
80(27) \\
69(23) \\
1(0.3)\end{array}$ \\
\hline $\begin{array}{l}\text { Veterinary-reported clinical } \\
\text { mastitis in parity } \\
\qquad \begin{array}{c}2 \\
\geq 3\end{array}\end{array}$ & $\begin{array}{l}\text { No } \\
\text { Yes } \\
\text { No } \\
\text { Yes } \\
\text { No } \\
\text { Yes }\end{array}$ & $\begin{array}{l}1590(87) \\
238(13) \\
1085(86) \\
182(14) \\
491(67) \\
237(33)\end{array}$ & $\begin{array}{l}276(93) \\
20(6.8) \\
268(91) \\
27(9.2) \\
204(72) \\
80(28)\end{array}$ \\
\hline
\end{tabular}


estimates provided by the program. Herd was assumed to follow a log-gamma distribution with parameter $\mathrm{g}$, which was algebraically integrated out.

Fixed model effects are listed in Table 2 . Age at $1^{\text {st }}$ calving and herd median age at 1 st calving were categorized by quintiles. Clinical mastitis indicated cow status regarding veterinary-reported clinical mastitis. Starting at $7 \mathrm{~d}$ precalving, a cow was coded as nonmastitic. If diagnosed with mastitis, she was coded as mastitic for the rest of the lactation. Cow housing represented the prevailing housing system for cows in the herd. Long-stalls, used in northern Europe, were tie-stalls where cows could be locked out from the feed at times when the farmer is not present. The herd incidence of clinical mastitis was based on cases of veterinary-reported clinical mastitis in project cows from $7 \mathrm{~d}$ precalving in lactations with a duration of $\leq 150 \mathrm{~d}$, and was calculated as a lactational incidence risk (categorized by tertiles). In one herd, none of the five cows reached $150 \mathrm{~d}$ in milk and these cows were coded as a fourth category. Herd mean milk production represented the herds' milk production level in a given calendar year ( $\mathrm{kg} \mathrm{ECM} /$ year, categorised by tertiles), based on milk recordings in all lactating cows. Housing from 3 to 7 months represented the housing system of a given cow during calfhood. 'Other' included cubicles and tie-stalls. Number of housing changes before 1st calving indicated the number of times the cow had been moved from one housing system to another during rearing. Relative milk yield represented the cows' daily milk yield $30 \mathrm{~d}$ postcalving in a given lactation as a normalised deviation from the herd mean in the same breed and parity. In each cow and lactation, daily yields were calculated from a model based on a sixth-degree polynome of time postcalving, estimated by linear regression of all cows' test-day milk recordings from 4 to $305 \mathrm{~d}$ in milk, separately within each breed and parity. The yields were normalised by subtracting the corresponding herdlevel mean and dividing by the herd-level standard deviation. These normalised deviations were categorized into seven unequally sized classes with 5, 5, 10, 20, 20, 20 and 20\% of the observations (lowest to highest). Lactations without values (cows culled or censored before $30 \mathrm{~d}$ postcalving; $2.3 \%$ of lactations) were set to the herd mean and, consequently, their deviations to 0. Pregnancy status represented the cross-classification between a given lactation stage and the lactation stage when the farmer was assumed to have knowledge about pregnancy. Both stages were defined as $0-30,31-60,61-150,151-240,241-305$, and $>305 \mathrm{~d}$ after calving, although no cows conceived before $61 \mathrm{~d}$ (non-pregnant cows received a separate code). The approach of Rajala-Schultz and Gröhn (1999b) was followed to estimate the time of farmers' awareness of pregnancy. Results from reported physical pregnancy checks performed by AI staff (75\% of lactations) were used to either confirm or change the estimated status. Year represented calendar year from 2000 to 2005 with a limited amount of cow-time in 1999 (1.3 cow-years or $0.024 \%$ of total cow-time) and 2006 (53 cow-years or $1.0 \%$ ) coded as 2000 and 2005, respectively. Month was calendar month grouped pairwise to achieve a manageable number of categories (January-February; March-April; May-June; July-August; September-October; November-December).

Independent variables tested for inclusion but not retained in the model $(\mathrm{P}>0.05)$ expressed or were related to herd size, existence of explicit herd aims for rearing of replacement heifers, month of birth, housing system until 3 months of age, diarrhoea and respiratory disease in different age categories, herd incidence of all reported calf diseases, indoor ammonia concentration during rearing, accumulated grazing time, grazing late in the autumn, heifer transition routines including concentrate feeding, growth rate from weaning to breeding, body condition score at 1 st breeding and at 1 st calving, body weight at $1^{\text {st }}$ calving, calendar year and month at 1 st calving, cow disease occurrence, and herd milk-cell counts.

For the presentation of effects, hazard ratios, their $95 \%$ confidence intervals and Student's t-test $\mathrm{P}$ values were calculated from estimates of coefficients and their standard errors. Estimates of time-dependent covariates cannot be separated from the general change of 
Table 2

Effects of rearing and confounding factors on the risk of culling according to a Weibull proportional hazards model and data from 2124 Swedish dairy cows born in 109 herds during 1998.

\begin{tabular}{|c|c|c|c|c|c|c|}
\hline $\begin{array}{l}\text { Fixed model } \\
\text { effect }\end{array}$ & Class & $\begin{array}{l}\text { Change in } \\
-2 \ln L^{\mathrm{a}}(\mathrm{df})\end{array}$ & $\begin{array}{l}\text { Likelihoo } \\
\text { d-ratio } \mathrm{P}^{\mathrm{b}}\end{array}$ & $\begin{array}{l}\text { Hazard } \\
\text { ratio }\end{array}$ & $\mathrm{P}^{\mathrm{c}}$ & $\begin{array}{l}95 \% \text { CI of } \\
\text { hazard ratio }\end{array}$ \\
\hline $\begin{array}{l}\text { Age at } 1^{\text {st }} \\
\text { calving }\end{array}$ & $\begin{array}{l}\leq 770 \mathrm{~d} \\
771-811 \mathrm{~d} \\
812-859 \mathrm{~d} \\
860-941 \mathrm{~d} \\
>941 \mathrm{~d}\end{array}$ & $10.8(4)$ & 0.029 & $\begin{array}{l}1 \\
1.1 \\
1.1 \\
1.2 \\
0.93\end{array}$ & $\begin{array}{c}- \\
0.19 \\
0.49 \\
0.030 \\
0.50\end{array}$ & $\begin{array}{c}- \\
0.95-1.3 \\
0.90-1.2 \\
1.0-1.4 \\
0.76-1.1\end{array}$ \\
\hline Breed $^{\mathrm{d}}$ & $\begin{array}{l}\text { Swedish Red } \\
\text { Swedish Holstein } \\
\text { Other or cross }\end{array}$ & $6.20(2)$ & 0.045 & $\begin{array}{l}1 \\
0.86 \\
1.0\end{array}$ & $\begin{array}{c}- \\
0.032 \\
0.90\end{array}$ & $\begin{array}{c}- \\
0.74-0.99 \\
0.71-1.5\end{array}$ \\
\hline $\begin{array}{l}\text { Clinical } \\
\text { mastitis }\end{array}$ & $\begin{array}{l}\text { No } \\
\text { Yes }\end{array}$ & $70.1(1)$ & $<0.0001$ & $\begin{array}{l}1 \\
1.8\end{array}$ & $<-$ & $1.6-2.0$ \\
\hline Cow housing ${ }^{\mathrm{d}}$ & $\begin{array}{l}\text { Cubicles } \\
\text { Short-stalls } \\
\text { Long-stalls }\end{array}$ & $5.65(2)$ & 0.059 & $\begin{array}{l}1 \\
1.3 \\
1.5\end{array}$ & $\begin{array}{c}- \\
0.084 \\
0.025\end{array}$ & $\begin{array}{c}- \\
0.97-1.7 \\
1.0-2.0\end{array}$ \\
\hline $\begin{array}{l}\text { Grazing before } \\
1^{\text {st }} \text { calving }\end{array}$ & $\begin{array}{l}\text { No } \\
\text { Yes }\end{array}$ & $4.87(1)$ & 0.027 & $\begin{array}{l}1 \\
1.3\end{array}$ & $\begin{array}{c}- \\
0.066\end{array}$ & $0.98-1.7$ \\
\hline $\begin{array}{l}\text { Herd incidence } \\
\text { of clinical } \\
\text { mastitis }^{\mathrm{d}}\end{array}$ & $\begin{array}{l}\leq 0.094 \\
0.095-0.16 \\
>0.16 \\
\text { Missing }\end{array}$ & $36.9(3)$ & $<0.0001$ & $\begin{array}{l}1 \\
1.4 \\
0.97 \\
39\end{array}$ & $\begin{array}{c}- \\
0.017 \\
0.85 \\
<0.0001\end{array}$ & $\begin{array}{c}- \\
1.1-1.9 \\
0.74-1.3 \\
9.9-152\end{array}$ \\
\hline $\begin{array}{l}\text { Herd mean milk } \\
\text { production }^{\text {de }}\end{array}$ & $\begin{array}{l}\leq 7370 \mathrm{~kg} \mathrm{ECM} \\
7371-8054 \mathrm{~kg} \text { ECM } \\
>8054 \mathrm{~kg} \mathrm{ECM}\end{array}$ & $0.218(2)$ & 0.90 & $\begin{array}{l}1 \\
0.98 \\
1.0\end{array}$ & $\begin{array}{c}- \\
0.80 \\
0.88\end{array}$ & $\begin{array}{c}- \\
0.84-1.1 \\
0.84-1.2\end{array}$ \\
\hline $\begin{array}{l}\text { Herd median age } \\
\text { at } 1^{\text {st }} \text { calving }\end{array}$ & $\begin{array}{l}\leq 785 \mathrm{~d} \\
786-811 \mathrm{~d} \\
812-842 \mathrm{~d} \\
843-889 \mathrm{~d} \\
>889 \mathrm{~d}\end{array}$ & $13.8(4)$ & 0.0080 & $\begin{array}{l}1 \\
0.88 \\
0.88 \\
0.67 \\
0.59\end{array}$ & $\begin{array}{c}- \\
0.50 \\
0.49 \\
0.027 \\
0.0075\end{array}$ & $\begin{array}{c}- \\
0.62-1.3 \\
0.62-1.3 \\
0.48-0.96 \\
0.40-0.87\end{array}$ \\
\hline $\begin{array}{l}\text { Housing from } 3 \\
\text { to } 7 \mathrm{mo}\end{array}$ & $\begin{array}{l}\text { Litter pen } \leq 12 \\
\text { calves } \\
\text { Litter pen }>12 \\
\text { calves } \\
\text { Slatted pen } \leq 7 \\
\text { calves } \\
\text { Slatted pen }>7 \\
\text { calves } \\
\text { Other }\end{array}$ & $13.1(4)$ & 0.0014 & $\begin{array}{l}1 \\
1.1 \\
1.2 \\
1.7 \\
1.1\end{array}$ & $\begin{array}{c}- \\
0.64 \\
0.12 \\
0.0017 \\
0.69\end{array}$ & $\begin{array}{c}- \\
0.75-1.6 \\
0.96-1.4 \\
1.2-2.4 \\
0.74-1.5\end{array}$ \\
\hline $\begin{array}{l}\text { Number of } \\
\text { breedings since } \\
\text { last calving de }\end{array}$ & $\begin{array}{l}0 \\
1 \\
\geq 2\end{array}$ & $249(2)$ & $<0.0001$ & $\begin{array}{l}1 \\
0.37 \\
0.34\end{array}$ & $\begin{array}{c}- \\
<0.0001 \\
<0.0001\end{array}$ & $\begin{array}{c}- \\
0.32-0.44 \\
0.30-0.40\end{array}$ \\
\hline $\begin{array}{l}\text { Number of } \\
\text { housing changes } \\
\text { before } 1^{\text {st }} \text { calving }\end{array}$ & $\begin{array}{l}2 \\
3 \\
4\end{array}$ & $8.35(2)$ & 0.0015 & $\begin{array}{l}1 \\
1.2 \\
1.4\end{array}$ & $\begin{array}{c}- \\
0.093 \\
0.0068\end{array}$ & $\begin{array}{c}- \\
0.98-1.4 \\
1.1-1.7\end{array}$ \\
\hline $\begin{array}{l}\text { Parity by } \\
\text { pregnancy } \\
\text { status }\end{array}$ & See Fig. 1 & $1262(64)^{e}$ & $<0.0001^{\mathrm{f}}$ & See Fig. 1 & - & - \\
\hline $\begin{array}{l}\text { Relative milk } \\
\text { yield }^{\text {de }}\end{array}$ & $\begin{array}{l}\leq-1.94 \\
-1.94--1.46 \\
-1.46--0.85\end{array}$ & $124(6)$ & $<0.0001$ & $\begin{array}{l}1 \\
0.70 \\
0.55\end{array}$ & $\begin{array}{r}- \\
0.0067 \\
<0.0001\end{array}$ & $\begin{array}{c}- \\
0.54-0.91 \\
0.44-0.69\end{array}$ \\
\hline
\end{tabular}




$\begin{array}{lrrr}-0.85--0.16 & 0.49 & <0.0001 & 0.40-0.59 \\ -0.16-0.33 & 0.68 & 0.0001 & 0.56-0.83 \\ 0.33-1.06 & 0.44 & <0.0001 & 0.36-0.54 \\ >1.06 & 0.37 & <0.0001 & 0.30-0.46\end{array}$

Year by season $^{\text {de }}$ See Fig. 2 $257(44)^{\mathrm{d}} \quad<0.0001^{\mathrm{f}} \quad$ See Fig. 2

${ }^{a}$ Change when effect is excluded from final model; full model $\_2 \ln L=26,507.24$.

${ }^{\mathrm{b}} \mathrm{P}$ value based on an approximate likelihood-ratio test of the effect.

${ }^{\mathrm{c}} \mathrm{P}$ value based on a Student's t-test comparing the coefficient estimate with the base level of the effect.

${ }^{\mathrm{d}}$ Confounder.

${ }^{\mathrm{e}}$ Time-dependent effect; remaining variables time-independent.

${ }^{\mathrm{f}}$ Both main effects and their interaction considered simultaneously.

the baseline function. Therefore, for the comparison of cows at different time points, the estimates of parity by pregnancy status were combined with the baseline hazard function at these points (Gröhn et al., 1997) and presented hazard ratios were based on median hazards within each covariate pattern (Fig. 1).

The generalized coefficient of determination $\mathrm{R}^{2}{ }_{\mathrm{M}}$ (Maddala, 1983) was used to estimate the proportion of total variation explained by the model. The statistic was calculated as $1-$ $\left(L_{R} / L_{U}\right)^{2 / n}$, where $n$ is the sample size and $L_{R}$ and $L_{U}$ the restricted and unrestricted (full model) maximum likelihoods.

\section{Results}

\subsection{General observations}

Among studied animals, 1724 (81\%) were slaughtered or died spontaneously and 104 (4.9\%) were sold live, while 296 (14\%) were censored. Among censored animals, 54\% were followed until April 2006 or longer. No herds were sold or left the study before the end of recording. In culled cows, observed median productive life time was $780 \mathrm{~d}$ (range 2-2241 d), and in censored animals it was $1669 \mathrm{~d}$ (range 135-2352 d). By 31 December 2001, 98\% of the cows had calved. The estimate of the shape parameter of the Weibull distribution ( $\rho$ ) was 1.6, which indicates an increasing culling risk with time, and the estimate of the scale parameter $(\lambda)$ was 0.0017 .

Mean $( \pm$ S.D.) herd size was $71( \pm 28)$ among culled and $72( \pm 27)$ among censored animals. Hultgren et al. (2008) reported on calfhood morbidity in essentially the same data. Mean age at 1 st calving was $28.2( \pm 3.9)$ months in culled cows and $29.0( \pm 4.1)$ months in censored cows. The overall incidence risk of veterinary-reported clinical mastitis during the productive lifetime was $31 \%$. The incidence was considerably higher in parities $\geq 3$ than in lower parities (Table 1).

\subsection{Effects of rearing and confounding factors}

Model results are shown in Table 2 and Figs. 1 and 2. Likelihood-ratio tests of model effects showed that all but two covariates contributed significantly $(\mathrm{P} \leq 0.05)$ to the model. The generalised $R^{2}{ }_{\mathrm{M}}$ was 0.65 . The estimate of $\gamma$ was 4.7 , corresponding to a herd variance of 0.24 and a Kendall's $\tau$ coefficient of concordance of 0.11 , indicating a low level of clustering by herd.

The model predicted cows that had been housed in slatted pens with $>7$ calves from 3 to 7 months to have a $219 \mathrm{~d}$ shorter median survival time than cows that had been kept in litter pens with $\leq 12$ calves. Cows that had changed housing system four times before 1 st calving had a $141 \mathrm{~d}$ shorter median survival time than cows with a history of two changes. The higher 


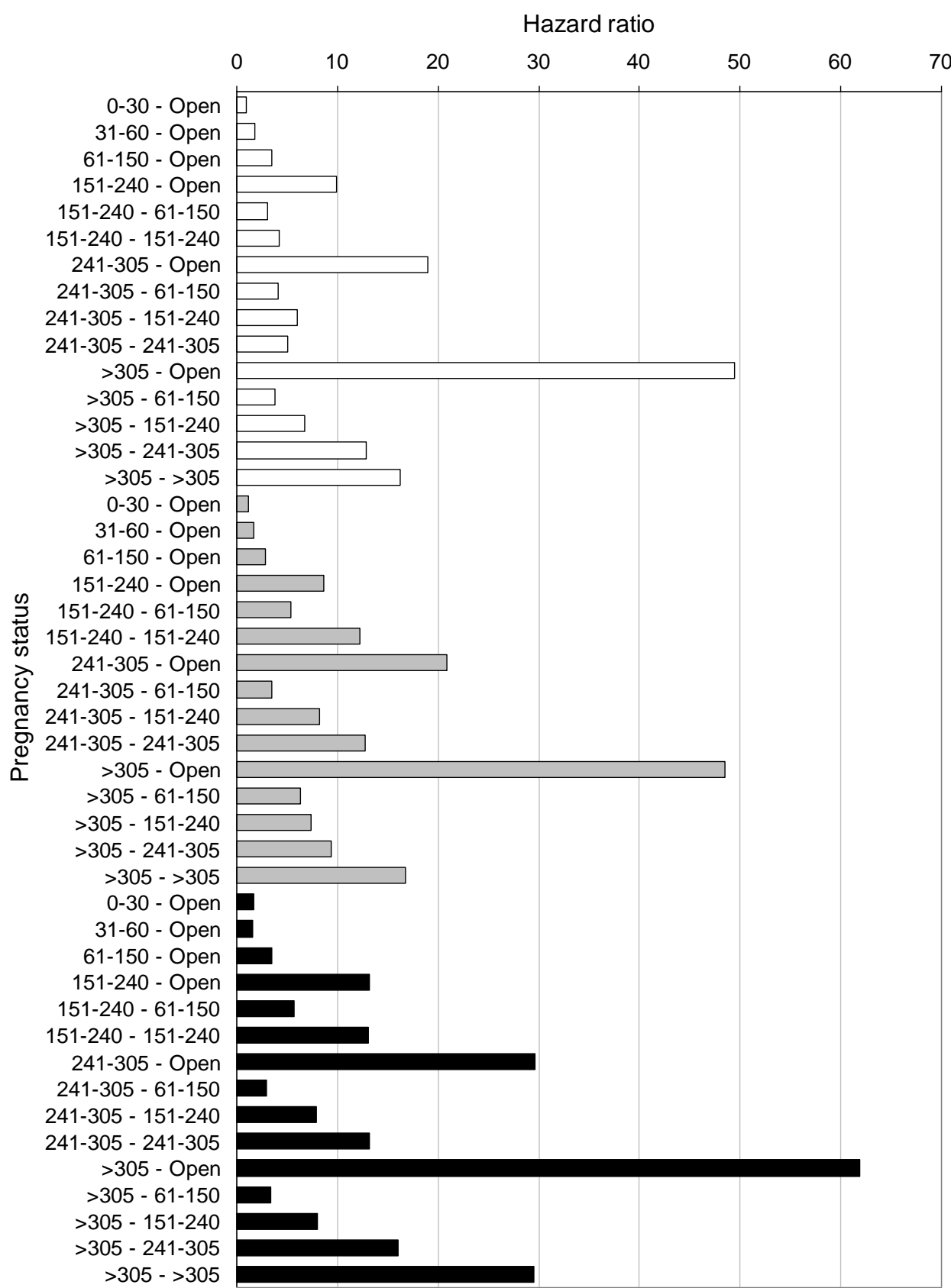

Fig. 1. Effect of parity and the cross-classification between a given lactation stage and the lactation stage when a cow was assumed to become pregnant on the risk of culling according to a Weibull proportional hazards model and data from 2124 Swedish dairy cows born in 109 herds during 1998. Parity is indicated by different shadings: white $=1 \mathrm{st}$; grey $=2 \mathrm{nd}$; black $=\geq 3 \mathrm{rd}$. 'Open' $=$ nonpregnant. Baseline hazard is included in each estimate, to make comparisons over time possible. The estimate of "241-305-241-305" is uncertain due to few (3) observed cullings.

median age at $1^{\text {st }}$ calving in the herd, the lower the culling hazard. Cows in herds with a median age at 1st calving >29.2 months had a 303 d longer median survival time than cows in herds with a median $\leq 25.8$ months. The relationship with individual age at 1 st calving was almost the opposite, although not as clearly linear; cows calving for the first time at an age of 28.2-30.9 months had higher culling risks than cows calving at $\leq 25.3$ months, and a tendency for higher risks than cows calving at $>30.9$ months $(\mathrm{P}=0.057)$. Cows in the highest class of relative milk yield were 2.7 times less likely to get culled than cows in the lowest class. Cows in the middle third of herds with respect to mastitis incidence were $40 \%$ more likely to get 


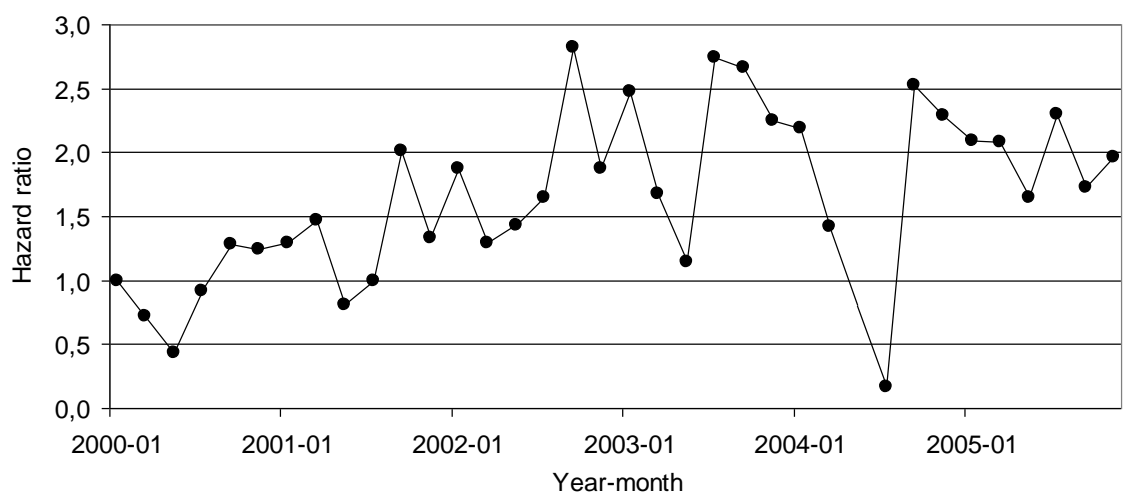

Fig. 2. Effect of calendar year and month on the risk of culling according to aWeibull proportional hazards model and data from 2124 Swedish dairy cows born in 109 herds during 1998. To facilitate interpretation, the points have been connected by a line although year-month is categorical. No culling was observed in May-June 2004. The values of March-April 2000 and July-August 2004 (lowest point) are uncertain due to few observed cullings.

culled than cows in other herds, and cows with mastitis were $80 \%$ as likely to get culled than non-mastitic cows.

The effect of year and month displayed a cyclic pattern with highest risks in the autumn and winter, and an increasing long-term trend. In 2005-2006, the risk of culling was approximately 2-4 times higher than in 1999-2000, excluding the baseline hazard function (Fig. 2). The effect of assumed pregnancy status was dramatic (Fig. 1). In all parities, the risk of culling was low for pregnant cows, but increased during the lactation and with time from calving when the cow conceived. In contrast, open cows had a much higher risk of culling, especially late in lactation. After day 305 of 1st lactation, a non-pregnant cow had a 16 times higher risk than a cow that had conceived before day 151. This ratio was lower in higher parities.

Fig. 3 shows predicted survival functions corresponding to six hypothetical cows, illustrating the relative importance of some key factors that result in successively increased hazards. Fifty percent survival was reached after $1505 \mathrm{~d}$ in cow 1 (day 5 of 5 th lactation), after 937 d in cow 2 (day 178 of 3rd lactation), after $780 \mathrm{~d}$ in cows 3 and 4 (day 400 of 2nd lactation), after $699 \mathrm{~d}$ in cow 5 (day 319 of 2nd lactation), and after $311 \mathrm{~d}$ of 1 st lactation in cow 6. Small fluctuations are due to effects of calendar time and pregnancy status.

\section{Discussion}

Fourteen percent of studied cows were censored, which is less than in most previous studies. This was achieved by forming a fixed cohort of animals born in 1998, and observing them for more than 4 years after $98 \%$ of the cows had calved. Censored cows were alike culled cows in most aspects recorded, with the exceptions of age at 1st calving, occurrence of veterinary-reported clinical mastitis, and, naturally, parity at end of recording. Although mean age at 1 st calvings were similar in the two groups, the distribution by calving-age classes differed. Clinical mastitis was less common in censored cows, which reflects the longer median productive life in this group. Because most censored animals were followed almost to the end of recording, and no censoring was due to herds being sold or leaving the study, we consider the censoring to be basically non-informative.

Housing in slatted pens with $>7$ calves between 3 and 7 months increased the risk of culling relative to litter pens. Pens with slatted floors were often of a minimum size to comply with animal welfare legislation (approximately $7-8 \mathrm{~m}^{2}$ per 5-7 calves). If an excess number of 


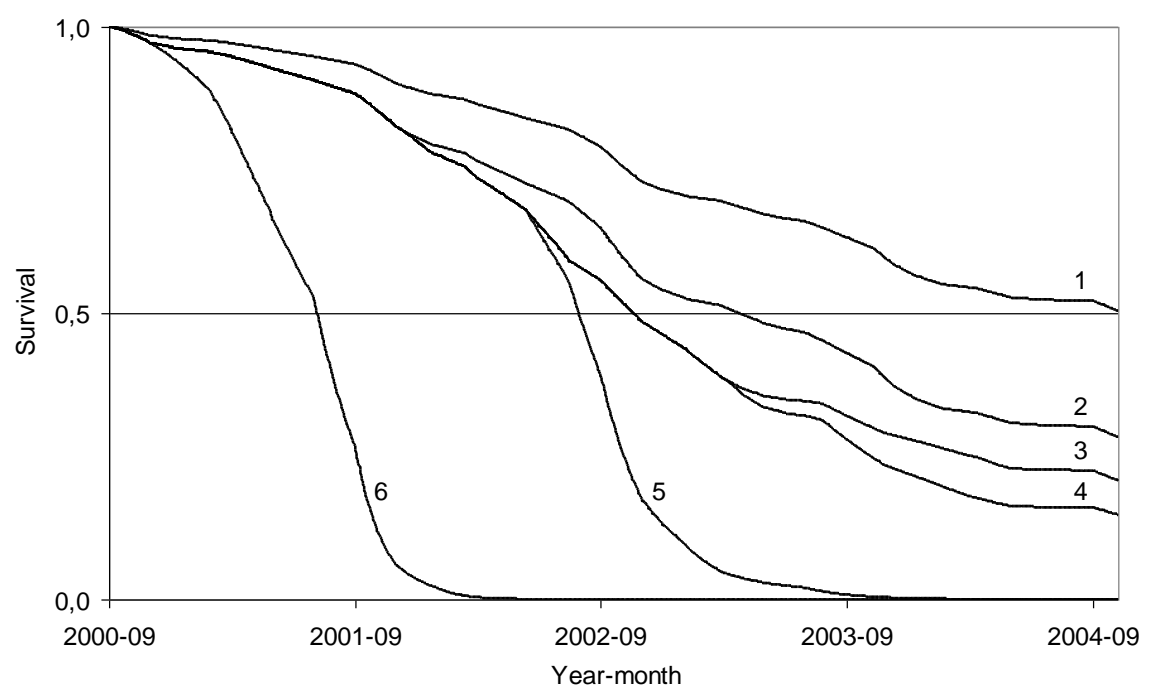

Fig. 3. Survival during $1500 \mathrm{~d}$ of production (maximum four lactations), corresponding to predicted azard functions of six hypothetical cows, all imagined to calve first time in September 2000, according to a Weibull proportional hazards model. Cow 1 was reared in a litter box of $\leq 12$ calves between 3 and 7 months of age, grazed as a heifer, calved for the first time at 27 months, conceived at 1st breeding in each lactation, and remained healthy. Cows $2-6$ were reared in a slatted box of $>7$ calves. Cow 2 was like cow 1 in all other respects. Cow 3 conceived late in 2 nd lactation, after three breedings, but was alike cow 2 in other respects. Cow 4 was alike cow 3, but contracted clinical mastitis at the beginning of her 4th lactation (although it did not affect substantially her milk yield). Cow 5 did not conceive in 2nd lactation and thus never reached parity 3. Cow 6 was never bred in 1st lactation.

calves was put in them it would have lead to increased crowding, with possible negative consequences for the animals, such as difficulties for all calves to simultaneously lie down comfortably. In contrast, littered pens for larger calf groups were usually more adapted to group size and generally larger. The effect of calf housing might therefore be explained by crowding, rather than flooring or group size.

We expected a negative influence of severe calfhood illness, such as respiratory disease, but although the study comprised 2124 animals there were relatively few such cases. The nonexistent effect might therefore be due to insufficient statistical power. Alternatively, the cases, although coded as severe, might have been comparatively mild or well managed. In a study of 460 calves in 2 herds, Britney et al. (1984) found calfhood navel or joint disease to shorten median length of productive life by 30 months, but found no significant effect of calfhood respiratory or gastrointestinal disease within $90 \mathrm{~d}$ of birth. When studying 787 animals in 25 herds without scoring calfhood diseases by severity, Warnick et al. (1994) found no statistically significant association between calfhood respiratory or gastrointestinal disease and survival after calving. However, they detected a tendency for decreased longevity due to dullness before $91 \mathrm{~d}$ of age, observed in $5.6 \%$ of the animals.

Swedish herdsmen do not always call for a veterinarian to examine diseased calves. Consequently, standard veterinary records are likely to underestimate true disease occurrence. Moreover, practices for calling might vary considerably between farms and over time, thus possibly introducing bias. On the other hand, farmer records might suffer from misdiagnoses and inconsistencies. To improve data quality, we made a follow-up of herdsman reports by bimonthly farm visits of project veterinarians, including clinical examinations of calves. Based on similar data from the same animals, Svensson et al. (2003) reported that only half the cases of pneumonia diagnosed by the project veterinarians had been observed by farmers. Although the chosen recording strategy might render comparisons with other studies more 
difficult, we believe it served its purpose. Our records are thus likely to cover most cases. Based on observations in essentially the same animals, Hultgren et al. (2008) concluded that the incidence figures reported by Waltner-Toews et al. (1986a,b), Gardner et al. (1990), Olsson et al. (1993), Warnick et al. (1994), and Heinrichs et al. (2005), where recordings were made primarily by herdsmen and included mostly antibiotic-treated cases, probably underestimated true disease incidences severely.

In a study of breeding performance based on records of the same animals, we showed that time to 1 st breeding and to calving increased with the time heifers were grazed (Hultgren et al., 2008). The result most likely reflected farmers' reluctance to inseminate heifers at pasture, because of extra labour or expected poor pregnancy results, and possibly reduced growth rates at pasture. Despite analytical control for calving age, cows grazed before 1st calving tended to have a shorter productive life, which might indicate poorer rearing management at pasture.

Unlike Silva et al. (1986), Neerhof et al. (2000), and Schneider et al. (2007), we found no consistently increasing trend in the effect of a cow's age at 1st calving on the risk of culling. Instead, model results suggest a curvilinear relationship between risk of culling and individual calving age, with a maximum risk at 28.2-30.9 months of age at 1st calving, which calls for further studies. In accordance with Syrstad (1979), Schneider et al. (2007) found survival to be especially poor for cows calving at $>33$ months of age, which $<10 \%$ of our project did. However, among cows that calved at 24-31 months (like 76\% of our cows), Schneider et al. (2007) described a tendency towards a curvilinear relationship, with cows that calved for the first time at 25 and 30 months at similar risk levels and intermediate cows at (numerically) higher risks, similarly to what our model predicted. We found a decreasing trend in the effect of herd median age at 1st calving, which is most likely due to management, e.g. voluntary culling.

In contrast to Schneider et al. (2007), we found Swedish Holstein cows to run a lower risk of culling than Swedish Reds. The difference is not negligible, and we expected the reverse relationship. Possibly, this finding is due to confounding. Smaller milk breeds (e.g. Jersey) were scarcely represented in our data, and coded in the same way as crosses.

Compared to cubicle housing, cows tied in long-stalls had a higher risk of culling, while short-stalls were intermediate. The found association might result from poorer housing conditions or a negative influence on cow conformation and durability of decreased freedom of movement in tie-stalls, with more involuntary culling due to reproductive failure or disease. Traditional Swedish dairy herds are relatively small with tie-stalls, pasture grazing from May to September, and feeding based on grass-clover silage as roughage, but there is presently a strong trend towards larger herds and cubicle systems. In our data, long-stalls were likely to represent old barns, cubicle systems to be new and short-stalls to be of intermediate age. We expected cubicle herds, being more high-producing, to have a higher rate of voluntary culling, which would counteract the observed relationship. On the other hand, new establishments would have growing herds with few voluntary cullings. We did not collect information on cow-barn age. To our knowledge, no previous study has included cow housing system in a survival analysis of culling risk.

Regarding effects of parity, pregnancy and lactation stage, our results are fairly consistent with earlier research. Beaudeau et al. (1995) found that failure of French Holsteins to conceive at 1 st service and more days open increased the risk of culling regardless of parity. Gröhn et al. (1998) showed that conception decreased the risk of culling sharply in North American Holsteins. Rajala-Schultz and Gröhn (1999b) reported that late conception increases the risk of culling in Finnish Ayrshires. Schneider et al. (2007) presented trends very similar to ours, although they found the difference between parities $\geq 2$ and parity 1 to be greater, and allowed also for interaction with clinical mastitis. 
During 2000-2005 in all Swedish herds, the incidence rate of veterinary-reported clinical mastitis was 15-16 cases per 100 lactations (Swedish Dairy Association, 2007), which accords well with our lifetime incidence estimate of $31 \%$ and the lifetime incidence of 25\% presented by Schneider et al. (2007). Both Oltenacu et al. (2000) and Schneider et al. (2007) stressed the importance of pregnancy status and lactation stage for the effect of mastitis. However, our focus was effects of (time-independent) rearing factors and we regarded clinical mastitis merely as a potential confounder. We thus judged the applied coding of mastitis to be suitable and sufficient. Depending on when disease occurred, Oltenacu et al. (2000) estimated mastitis to increase the risk of culling by 1.3-2.8 times, and Rajala-Schultz and Gröhn (1999a, b) by 1.3-2.4 times. Schneider et al. (2007) reported the hazard ratio for mastitis to vary greatly but to reach 1.3-1.5 in most lactation-stage and pregnancy categories. These results accord with our hazard-ratio estimate of 1.8.

Like Schneider et al. (2007), we observed a seasonal effect with the highest risks of culling in the autumn or winter, when most calvings occur and require the farmers to find more room for new lactating cows. Schneider et al. (2007) revealed a slightly decreasing long-term risk trend, based on observations in cows calving for the first time in 1988-1996. In contrast, using a fixed birth cohort, we found an increasing trend over time from 1999 to 2006. Neither Schneider et al. (2007) nor we included the baseline hazard function in these estimates; in both cases this would have enhanced the increasing trend. Due to the fact that most of our project cows calved within a short period of time, our hazard-ratio estimates of calendar time might have been more affected by the increasing trend that would otherwise be expressed by the baseline hazard function.

We did not show any influence of herd size. The number of cows in herds is related to management practices and the net effect on culling rates is hard to predict. For instance, large herds were probably established more recently, which might have decreased culling rates. On the other hand, managers of large herds could have been more inclined to utilize the genetic merits of replacements, thus increasing culling rates. The restricted sampling frame probably reduced the possibilities to detect herd-size effects. Neither Rajala-Schultz and Gröhn (1999b) nor Schneider et al. (2007) included herd size in their models.

In the present study, data were from 109 herds selected for geographical location, enrolment in official recording schemes, herd size, assumed capability of farmers to keep reliable calf records, and farmer willingness to participate in the study. In 1997, the official schemes comprised $72 \%$ of the Swedish herds, $36 \%$ of the herds had less than 25 cows, and only 5.5\% had 75 cows or more (Swedish Dairy Association, 1998). Mean herd size was 30 cows and increasing. The studied herds represented $22 \%$ of all dairy herds in the selected county, or $0.7 \%$ of all Swedish dairy establishments at the time of selection (Statistics Sweden, 1999). It cannot be excluded that the selection introduced some bias with respect to effects on culling. For instance, farmers who perceived calf health problems in their herds, alternatively farmers with high ambitions regarding replacement rearing, might have been more inclined to participate. In fact, Svensson et al. (2003) showed that selected herds were larger and more high-producing than comparable herds by the time of selection, although there were no important differences with respect to housing systems or management routines. Svensson et al. (2006b) also showed that selected herds were larger and had higher herd milkproduction levels in 2001 than reference herds representative for all Swedish herds. Median age at 1st calving was relatively high but consistent with official data for all Swedish herds (Swedish Dairy Association, 2007). Like Svensson et al. (2006a), we conclude that the study herds were a reasonably representative sample of family dairy operations in southwest Sweden. 


\section{Conclusions}

The present study shows that rearing factors affect the productive life time of dairy cows in Swedish family operations. The risk of culling increases with housing in large-group slatted pens from 3 to 7 months of age, comparing with litter pens, with numerous changes in housing system during the rearing period, and with calving for the first time between 28 and 31 months of age, compared to $\leq 25$ months. The farmer's knowledge of pregnancy status, occurrence of veterinary-reported clinical mastitis, and milk yield all affect culling decisions dramatically. Cows in long-stall herds run a higher risk of culling than loose-housed cows.

\section{Acknowledgements}

We acknowledge the assistance of participating farmers for their dedication and support, and Ulf Emanuelson, Sven-Ove Olsson, Mats Pehrsson and Kerstin Plym Forshell for valuable contributions. We also thank the Swedish Dairy Association and Skara Semin regional dairy services for providing us with production and health data. Karin Lundborg, Lotta Andersson and Jonica Östlund performed excellent on-farm recordings and Gunilla Jacobsson assisted in data editing. The study was supported financially by the Swedish Farmers' Foundation for Agricultural Research.

\section{References}

Andersson, L., 1988. Swedish dairy herd health programmes based on routine recording of milk production, fertility data, somatic cell counts and clinical diseases. In: Ekesbo, I. (Ed.), Proceedings of the 6th International Congress on Animal Hygiene, vol. 1, Skara, Sweden, pp. 190-194.

Beaudeau, F., Ducrocq, V., Fourichon, C., Seegers, H., 1995. Effect of disease on length of productive life of French Holstein dairy cows assessed by survival analysis. J. Dairy Sci. 78, 103-117.

Britney, J.B., Martin, S.W., Stone, J.B., Curtis, R.A., 1984. Analysis of early calfhood health status and subsequent dairy herd survivorship and productivity. Prev. Vet. Med. 3, 45-52.

Ducrocq, V., Sölkner, J., 1998. The Survival Kit—a Fortran package for the analysis of survival data. In: Proceedings of the 6th World Congress on Genetics Applied to Livestock Production, Armidale, Australia, pp. 447-448.

Emanuelson, U., 1988. The national Swedish animal disease recording system. In: Willeberg, P., Agger, J.F., Riemann, H.P. (Eds.), Proceedings of the 5th International Symposium on Veterinary Epidemiology and Economics, Copenhagen, 25-29 July, 1998. Acta Vet. Scand. 29 (Suppl. 84), 262-264.

Ettema, J.F., Santos, J.E.P., 2004. Impact of age at calving on lactation, reproduction, health, and income in first-parity Holsteins on commercial farms. J. Dairy Sci. 87, 2730-2742.

Gardner, I.A., Hird, D.W., Utterback, W.W., Danaye-Elmi, C., Heron, B.R., Christiansen, K.H., Sischo, W.M., 1990. Mortality, morbidity, case fatality, and culling rates for California dairy cattle as evaluated by the national animal health monitoring system, 1986-87. Prev. Vet. Med. 8, 157-170.

Gill, G.S., Allaire, F.R., 1976. Relationship of age at first calving, days open, days dry, and herdlife to a profit function for dairy cattle. J. Dairy Sci. 59, 1131-1139.

Goodger, W.J., Fetrow, J., Ferguson, G.M., Trout, H.F., McCabe, R., 1989. A computer spreadsheet program to estimate the cost of raising dairy replacements. Prev. Vet. Med. 7 , 239-254. 
Gröhn, Y.T., Ducrocq, V., Hertl, J.A., 1997. Modeling the effect of a disease on culling: an illustration of the use of time-dependent covariates for survival analysis. J. Dairy Sci. 80, 1755-1766.

Gröhn, Y.T., Eicker, S.W., Ducrocq, V., Hertl, J.A., 1998. Effect of diseases on the culling of Holstein dairy cows in New York state. J. Dairy Sci. 81, 966-978.

Heinrichs, A.J., Heinrichs, B.S., Harel, O., Rogers, G.W., Place, N.T., 2005. A prospective study of calf factors affecting age, body size, and body condition score at first calving of Holstein dairy heifers. J. Dairy Sci. 88, 2828-2835.

Hultgren, J., Svensson, C., Maizon, D.O., Oltenacu, P.A., 2008. Rearing conditions, morbidity and breeding performance in dairy heifers in southwest Sweden. Prev. Vet. Med. 87, 244-260.

Maddala, G.S., 1983. Limited-dependent and Quantitative Variables in Econometrics. Cambridge University Press.

Neerhof, H.J., Madsen, P., Ducrocq, V.P., Vollema, A.R., Jensen, J., Korsgaard, I.R., 2000. Relationships between mastitis and functional longevity in Danish Black and White dairy cattle estimated using survival analysis. J. Dairy Sci. 83, 1064-1071.

Nilforooshan, M.A., Edriss, M.A., 2004. Effect of age at first calving on some productive and longevity traits in Iranian Holsteins of the Isfahan Province. J. Dairy Sci. 87, 2130-2135.

Olsson, S.-O., Viring, S., Emanuelson, U., Jacobsson, S.-O., 1993. Calf diseases and mortality in Swedish dairy herds. Acta Vet. Scand. 34, 263-269.

Oltenacu, P.A., Carvalheira, J., Emanuelson, U., Ducrocq, V., 2000. Effect of age, stage of lactation, milk yield and health events on length of productive life in Swedish dairy cattle assessed by survival analysis. In: Proceedings of the 49th Annual Natural Breeders' Roundtable, St. Louis, MO, USA, 4-5 May, 2000, pp. 61-72.

Ponce de León, R., Guzmán, G., 1989. Effect of age at calving on the longevity and survival of the Holstein. Cuban J. Agric. Sci. 23, 233-241.

Rajala-Schultz, P.J., Gröhn, Y.T., 1999a. Culling of dairy cows. Part I. Effects of diseases on culling in Finnish Ayrshire cows. Prev. Vet. Med. 41, 195-208.

Rajala-Schultz, P.J., Gröhn, Y.T., 1999b. Culling of dairy cows. Part II. Effects of diseases and reproductive performance on culling in Finnish Ayrshire cows. Prev. Vet. Med. 41, 279-294.

Schneider, M. del P., Strandberg, E., Emanuelson, U., Grandinson, K., Roth, A., 2007. The effect of veterinary-treated clinical mastitis and pregnancy status on culling in Swedish dairy cows. Prev. Vet. Med. 80, 179-192.

Silva, H.M., Wilcox, C.J., Spurlock, A.H., Martin, F.G., Becker, R.B., 1986. Factors affecting age at first parturition, lifespan and vital statistics of Florida dairy cows. J. Dairy Sci. 69, $470-476$.

Statistics Sweden, 1999. Jordbruksstatistisk årsbok 1999 (Yearbook of agricultural statistics 1999). Stockholm Report.

Svensson, C., Hultgren, J., Oltenacu, P.A., 2006a. Morbidity in 3-7-month old dairy calves in south-western Sweden, and risk factors for diarrhea and respiratory disease. Prev. Vet. Med. 74, 162-179.

Svensson, C., Nyman, A.-K., Persson Waller, K., Emanuelson, U., 2006b. Effects of housing, management, and health of dairy heifers on first-lactation udder health in southern Sweden. J. Dairy Sci. 89, 1990-1999.

Svensson, C., Lundborg, K., Emanuelson, U., Olsson, S.-O., 2003. Morbidity in Swedish dairy calves from birth to $90 \mathrm{~d}$ of age and individual calf-level risk factors for infectious diseases. Prev. Vet. Med. 58, 179-197.

Swedish Dairy Association, 2007. Cattle Statistics 1997/1998...2007. Stockholm, Sweden. Reports issued from 1998 to 2006. 
Syrstad, O., 1979. Survival rate of dairy cows as influenced by herd production level, age at first calving, and sire. Acta Agric. Scand. 29, 42-44.

Tozer, P.R., Heinrichs, A.J., 2001. What affects the costs of raising replacement dairy heifers: a multiple-component analysis. J. Dairy Sci. 84, 1835-1844.

Waltner-Toews, D., Martin, S.W., Meek, A.H., 1986a. The effect of early calfhood health status on survivorship and age at first calving. Can. J. Vet. Res. 50, 314-317.

Waltner-Toews, D., Martin, S.W., Meek, A.H., McMillan, I., 1986b. Dairy calf management, morbidity and mortality in Ontario Holstein herds. I. The data. Prev. Vet. Med. 4, 103124.

Warnick, L.D., Erb, H.N., White, M.E., 1994. The association of calfhood morbidity with first-lactation calving age and dystocia in New York Holstein herds. Kenya Vet. 18, 177179. 